\title{
Průzkum sbírky fonografických válečků Českého muzea hudby
}

Barbora Mašek Benetková, Martin Mejzr, Radka Šefců, Filip Šír

\section{Survey of the Phonographic Cylinders Collection of National Museum - Czech Museum of Music}

Abstract: The paper presents the interdisciplinary survey of the phonographic cylinders collection of National Museum - Czech Museum of Music. The text was created for the New Phonograph: Listening to the History of Sound project. The paper focuses on the characterisation of long-term storage of the collection and a common form of degradation - a fair overlay on the cylinder's surface. As for dealing with the wide spectrum of samples in the collection, the survey is focused on the most commonly occurring phonographic cylinders and their enclosures. A representative selection of samples was analysed to clarify the character of the degradation products and its origin.

Keywords: audio documents, phonographic cylinders, long-term storage, instrumental analysis

\section{Úvod}

Součástí sbírky fonotéky Národního muzea - Českého muzea hudby (ČMH) je kromě početného sbírkového fondu gramofonových desek i významná a rozsáhlá kolekce cca 1200 fonografických válečků. $S$ výjimkou několika interních pokusů o částečný přepis jejich zvukového obsahu v průběhu osmdesátých a devadesátých let minulého století nebyla tomuto fondu věnována prakticky žádná pozornost. Aktivity aktuálního projektu Národního muzea pod názvem Nový fonograf: naslouchejme zouku historie ${ }^{1}$, jehož cílem je vytvořit procedury, postupy, nástroje a strategie pro uchovávání historických zvukových dokumentů (včetně fonografických válečků) v českých pamětových institucích, dávají jedinečnou príležitost $\mathrm{k}$ hlubšímu zájmu o tuto sbírku za využití soudobých komplexních metod a př́stupů na poli ochrany zvukového kulturního dědictví. Předkládaný článek prezentuje dosavadní výsledky probíhajícího průzkumu sbírky fonografických válečků ve fonotéce ČMH se zaměřením na fyzické uložení sbírky a možnosti jeho optimalizace.

\section{Fonografické válečky - historie a základní typologie}

Fonografické válečky jsou nejstarším typem moderního, pro komerční účely masově vyráběného a distribuovaného zvukového nosiče, který má tvar dutého válce (cylindru), na jehož vnějším plášti je v drážce uchována zvuková stopa. Vynález záznamu zvuku je navždy spojen se jménem Thomase Alvy Edisona, který zkonstruoval svůj př́stroj zvaný fonograf v roce 1877 ve své laboratoři v Menlo Parku v americkém státě New Jersey. Navázal na pokusy některých svých předchůdců, kteří s technologií akustiky nezávisle na sobě experimentovali již několik desítek let před ním. ${ }^{2}$ Až po více než deseti letech od vynálezu, během kterých se do vylepšování př́strojů, inovací v rámci použitých materiálů i snah o levnější proces výroby vložili i další vynálezci a firmy, se z fonografu a jeho záznamového nosiče (tedy fonografického válečku) stalo první zvukové médium masového využití. Kromě zamýšleného použití v byrokratické praxi (jako svého druhu diktafonu) či pro vědecké účely (etnografické nebo jazykovědné) stál fonograf po roce 1889 i za rozvojem moderního hudebního průmyslu. ${ }^{3}$

Pro období čtyřiceti let komerční výroby fonografických válečků (1889-1929) rozeznáváme poměrně širokou škálu jejich typů, lišících se druhem použitého materiálu, fyzickými parametry a dalšími výrobně-technologickými faktory (rychlost
1 Práce byla financována z programu NAKI II Ministerstva kultury České republiky v rámci projektu Nový fonograf: naslouchejme zvuku historie. Vytvoření postupů a nástrojư pro evidenci, digitalizaci, zpřistupnění a dlouhodobou ochranu zvukových záznamů na historických nosičich $v$ pamětových institucích, DG18PO2OVVO32.

2 Známé i polozapomenuté Edisonovy předchůdce (jako byl např. Édouard-Léon Scott de Martinville) mapuje $v$ kontextu celkové transformace moderní vědecko-technologické praxe např. STERNE, Jonathan. The Audible Past: Cultural Origins of Sound Reproduction. Durham: Duke University Press, 2003. 3 Výběrově HOSŤ́A, Jan. Katalog fonografů ve sbirkách NTM. Praha: NTM, 2018; GELATT, Roland. The Fabulous Phonograph. Philadelphia and New York: J.B. Lippincott Company, 1954.

Ing. Barbora Mašek Benetková, Ph.D. Vysoká škola chemickotechnologická v Praze Barbora.Benetkova@vscht.cz

Mgr. et Bc. Martin Mejzr Národní muzeum martin.mejzr@nm.cz

Ing. Radka Šefců Národní galerie Praha radka.sefcu@ngprague.cz

Filip Šír, DiS.

Národní muzeum

filip.sir@nm.cz 


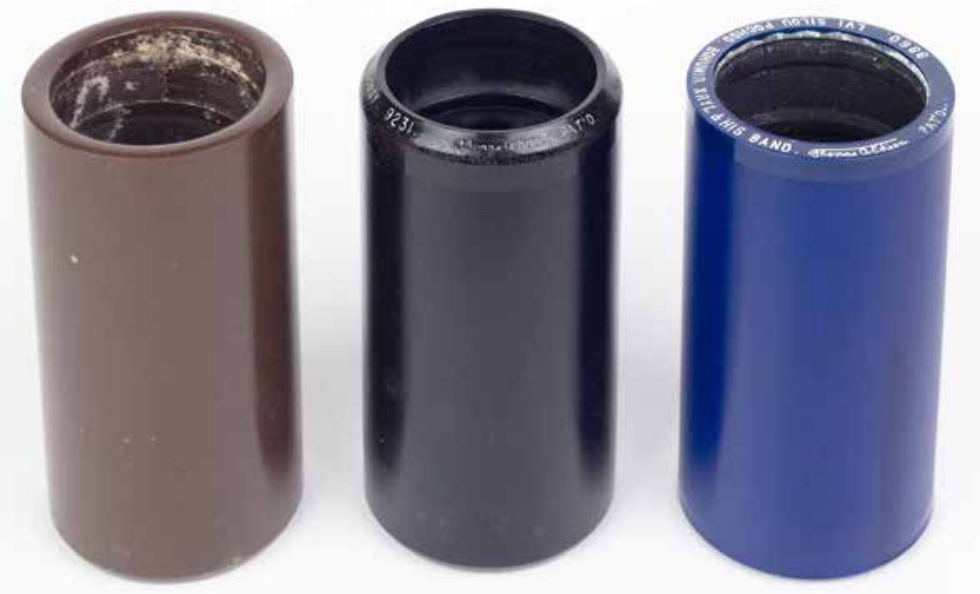

Obr. 1. Nejčastěji dochované typy fonografických válečků - voskové válečky (hnědý

a černý) a celuloidový váleček (série Blue Amberol).

4 Hlavními složkami celuloidu je nitrát celulózy s kafrem a alkoholem viz MLEZIVA, Josef.

Polymery - výroba, struktura, vlastnosti a použití. Praha: Sobotáles, 1993, s. 340-342.

5 Prírodní vosky (rostlinného nebo živočišného původu) jsou směsi esterů vyšších mastných kyselin s délkou uhlíkového řetězce C16-C36 a vyšších alkoholü, volných nasycených kyselin s délkou uhlíkového retězce C24-C30, uhlovodíků a vyšších alkoholů viz KUBIČKA, Roman a ZELINGER, Jiři, Výkladový slovník malírství, grafiky a restaurátorství.

Praha: Grada Publishing, 2004, s. 319-320; TULLOCH, A.P.

Beeswax-composition and analysis. Bee World, 1980, vol.

61, s. 47-62.

6 SHAMBARGER, Peter.

Cylinder Records: An Overview. ARSC Journal. 1995, vol. 26, no. 2, s. 133-161.

7 KLINGER, Bill. Cylinder Records: Significance,

Production, and Survival [online]. Library of Congress, 2007. s. 2-3. [cit. 2020-07-08]. Dostupné z: https://www.loc. gov/static/programs/national-recording-preservation-board/ documents/klinger.pdf. Srov. HOSŤ́́K 2018. s. 135-136, cit. $v$ pozn. 3.

8 Druhou největší sbírkou $v$ rámci ČR co do počtu nosičù je kolekce fonografických válečků v Národním technickém muzeu v Praze (NTM), která obsahuje cca 1000 nosičů. přehrávání, celková doba záznamu, rozměry, konstrukce a tvar válečku atd.). Základní rozdělení je založené na materiálovém složení, přičemž lze rozeznat dva typy válečků - voskové a celuloidové $^{4}$ fonografické válečky (obr. 1).

Starší typ - voskové válečky, vznikl v průběhu osmdesátých let 19 . století a jeho složení prodělalo poměrně dynamický vývoj. Od experimentálních bílých válečků, které byly složeny $z$ různých druhů přírodních voskư ${ }^{5}$, přes hnědé válečky dominující v devadesátých letech 19. století a počátku století následujícího až po válečky z černého vosku, které i přes inovace $\mathrm{v}$ technologii výroby nedokázaly před první světovou válkou konkurovat nástupu gramofonové desky. ${ }^{6}$

V devadesátých letech 19. století použil celuloid pro výrobu fonografických válečků francouz Henri Lioret. Masová produkce celuloidových válečků však odstartovala až po roce 1900 . Za vrcholné období můžeme označit léta 1912-1929, kdy Edisonova společnost vydávala sérii Blue Amberol s charakteristickou elegantní výrazně modrou barvou. Rokem 1929 končí komerční výroba válečků, v menší míře však přetrvala jak v Evropě, tak v USA specializovaná produkce a distribuce nosičů převážně $\mathrm{z}$ hnědého vosku pro účely byrokratické, novinářské a pedagogické praxe až do šedesátých let 20. století.?

\section{Průběh průzkumu sbírky}

Sbírka fonografických válečků ve fonotéce ČMH se řadí mezi největší sbírky tohoto druhu v pamětových institucích v České republice. ${ }^{8}$ Jejímu zhodnocení a historickému výzkumu doposud bylo věnováno jen velmi málo pozornosti. Za stěžejní lze považovat kapitoly v průkopnickém díle Přehled zvukového průmyslu od Jindřicha Mesznera. ${ }^{9}$ Ten se ve své práci zaměřil na systematické mapování českých snímků vydávaných tehdejšími světovými a lokálními společnostmi i na popis nekomerční produkce. Nesmírně cenný je především jeho přehled a popis snímků na fonografických válečcích datovaných do období let 19021905, které vznikly v okruhu pěvců tzv. Tesařovské opery a jsou jádrem sbírky fonotéky ČMH. Studiu fonografických válečků s českým obsahem se věnoval také Gabriel Gössel, jehož poznatky s přesahem do kontextu jejich výroby, distribuce a prodeje lze aplikovat i pro poznání sbírky v ČMH. ${ }^{10}$

Interdisciplinární průzkum byl realizován v několika etapách v letech 2019-2020 s cílem posoudit fyzický stav sbírky, identifikovat a charakterizovat materiály jak ochranných obalů fonografických válečků, tak samotné jejich hmotné podstaty. Celkový počet 1158 evidovaných fonografických válečků byl rozdělen na základě několika kritérií. $V$ prvé řadě proběhlo statistické zhodnocení zastoupení jednotlivých typů válečků, a zároveň byly roztříděny ochranné obaly na základě jejich vzhledové rozmanitosti, tedy podle druhu etikety či obchodní značky.

Z průzkumu vyplynula převaha hnědých a černých voskových fonografických válečků (tab. 1). Celuloidové válečky jsou ve sbírce zastoupeny pouze dvěma exemplári. $Z$ toho důvodu se průzkum a laboratorní analýzy zaměřily na hnědé a černé voskové válečky.

\section{Hnědé voskové fonografické válečky}

Předchůdcem hnědých voskových válečků byly bílé válečky, tvořeny proměnlivou směsí zviŕrecích, rostlinných a minerálních vosků s př́davkem karnaubského vosku. ${ }^{11}$ Nízký bod tání a s tím spojená měkkost vosků způsobovaly potíže spojené zejména se zborcením tvaru a nízkou odolností vůči mechanickému poškození. Při hledání odolnějších a pro masovou 
Tab. 1. Statistické vyhodnocení jednotlivých typů fonografických válečků ve sbírce ČMH.

\begin{tabular}{|l|l|l|}
\hline Typ válečku & Období výroby/produkce & Zastoupení ve fonotéce ČMH [ks] \\
\hline Voskový bílý & $1887-1889$ & 0 \\
\hline Voskový hnědý & $1889-$ cca 1960 & 224 \\
\hline Voskový černý & $1902-1912$ & 932 \\
\hline Celuloidový & $1900-1929$ & 2 \\
\hline
\end{tabular}

výrobu dostupnějších náhražek přírodních druhů vosků začaly být testovány směsi mastných kyselin s jejich solemi. Nejčastěji používanými byly kyseliny stearová a palmitová $\mathrm{s}$ jejich sodnými a hlinitými solemi. Další složkou vyskytující se např́č všemi typy voskových válečků je ceresin (minerální vosk). ${ }^{12}$ Přestože se oproti předcházejícím bílým válečkům nejednalo pouze o směs prírodních vosků, zůstalo jim typologické označení „,voskové" díky společné složce a některým podobným vlastnostem, jako vzhled, tvarovatelnost a dotykový vjem. ${ }^{13}$ Díky jejich zavedení do masové produkce na přelomu osmdesátých a devadesátých let 19. století byla vytvořena první historická varianta komerčně vydávaných válečků, které jsou dnes nazývány podle své barvy jako hnědé válečky. Rozpětí jejich barevné tonality je od béžové či světle krémové až po tmavě hnědý odstín hořké čokolády. Výsledná barevnost je ovlivněna dobou a teplotními podmínkami výroby. ${ }^{14}$

\section{Černé voskové fonografické válečky}

Další historický přelom $\mathrm{v}$ produkci fonografických válečků nastal krátce po přelomu století zavedením voskových válečků černé barvy, které byly prefabrikovány za pomoci forem/kadlubů. Používání zlata (byt๋ v minimálním množství) při výrobě těchto forem pro odlévání kopií válečkư ${ }^{15}$ vedlo v př́padě Edisonovy společnosti $\mathrm{k}$ označení nové komerční série válečků jako Gold-Moulded (v německy mluvícím prostředí jako Goldguss Walze, $\mathrm{v}$ češtině pak $\mathrm{s}$ přiléhavým názvem zlatolité válce). Tento typ, charakteristický svou vyšší tvrdostí, byl Edisonem zaveden do prodeje roku 1902. Konkurenční
Columbia přispěchala s prodejem odlévaných válečků černé barvy hned roku následujícího. ${ }^{16}$

Chemické složení černých voskových fonografických válečků prošlo mnoha obměnami. Společnými složkami byly zejména kyselina stearová, uhličitan sodný, hydroxid sodný a kovová příměs (měd, hliník). Charakteristickou černou barvu dodávala hmotě lampová čerň, která byla používána $\mathrm{v}$ kombinaci $\mathrm{s}$ karnaubským voskem. $V$ některých receptech byla tato směs zaměněna za ebonit. ${ }^{17} \mathrm{~V}$ ojedinělých př́padech jsou uváděny i formulace bez voskové složky, kdy byl ceresin zcela vynechán. ${ }^{18}$

Na rozdíl od hnědých válečků, které byly díky nižší tvrdosti přepisovatelné, chtěli výrobci zavedením prefabrikátů docílit jednak rychlejší a levnější výroby při větší odolnosti materiálu, a také zabránit jejich pirátskému šíření. Po černých voskových válečcích přichází kvalitativní skok ve složení ve spojení s výrobou fonografických válečků celuloidových. Ty byly $\mathrm{v}$ různých obměnách produkovány až do roku 1929. ${ }^{19}$

\section{Uchovávání fonografických válečků}

Nejčastějším způsobem uložení byl lignocelulózový, většinou lepenkový ochranný obal válcovitého tvaru kopírující tvar fonografického válečku, do kterého byly nosiče vkládány jednotlivě. Tyto obaly ve formě krabiček, tubusů, byly označeny př́slušnými etiketami a obchodními známkami výrobců a distributorů. Víčko ochranného obalu bylo využíváno jako prostor pro základní informace o dané nahrávce (titul skladby, autor, př́padně interpret, výrobní číslo nahrávky,
Za poskytnutí informací děkujeme Janu Hostákovi a Renému Melkusovi.

9 MESZNER, Jindřich. Přehled zvukového průmyslu: studijní materiály. Strojopis, 1984, s. $29-40$.

10 GÖSSEL, Gabriel.

Fonogram 1: Praktický průvodce historií záznamu zvuku. Praha: Radioservis, 2001, s. 6975; GÖSSEL, Gabriel a ŠíR, Filip. Recorded Sound in the Czech Lands 1900-1946. Brno: Moravská zemská knihovna, 2016, s. 15-19.

11 WILE, Raymond R. Cylinder Record Materials. ARSC Journal. vol. 26, no. 2, 1995. s. 163. Srov. SHAMBARGER 1995, s. 139, cit. v pozn. 6. Karnaubský vosk je prírodní vosk získaný z listů brazilské palmy karnaubské (Copernicia cerifera) viz KUBIČKA a ZELINGER 2004, s. 318, cit. $v$ pozn. 5.; TAUBE, Edward. Carnauba Wax: Product of a Brazilian Palm. Economic Botany. 1952, vol. 6, no. 4, s. 379-401.

12 Vosk s mikrokrystalickou strukturou získávaný v minulosti z ozokeritu (bituminózní zemní vosk) skládající se $z$ nasycených uhlovodiků $s$ dlouhým řetězcem C20-C32, viz KUBIČKA - ZELINGER 2004, s. 42, cit. v pozn. 5; Ceresin wax [online]. CAMEO Materials Database [cit. 2020-11-18]. Dostupné z: http://cameo.mfa. org/wiki/Ceresin_wax 13 WILE 1995, s. 164, cit. $v$ pozn. 11.

14 Ibidem; MONROE. Eric $B$. Uncovering the nature of damage to early wax cylinder audio recordings during storage [online]. AES International Conference on Audio

Archiving, Preservation and Restoration, 2018 June 7-9, 
Culpeper, VA, USA. s. 3. [cit. 2020-07-02]. Dostupné z: https://www.aes.org/e-lib/browse. cfm?elib=19591.

15 Přehled různých způsobů výroby kopií fonografických válečků včetně popisu výše zmíněného poskytuje MORTON, David. Sound recording: the life story of a technology. Baltimore, Md.: Johns Hopkins University Press, 2006, s. $26-28$.

16 KLINGER 2007, s. 4, cit. $\checkmark$ pozn. 7.

17 Sírou vulkanizovaný kaučuk černé barvy, s obsahem síry 25-50 dsk. Viz PROKOPOVÁ, Irena. Makromolekulární chemie. 2nd ed. Vysoká škola chemicko-technologická v Praze, Praha 2007, s. 200.

18 WILE 1995, s. 166-168, cit. $v$ pozn. 11.

19 KLINGER 2007, s. 2-5, cit. $\checkmark$ pozn. 7.

20 SHAMBARGER 1995,

s. 147-153, cit. v pozn. 6 .

21 Ibidem. s. 146. Srov. KLINGER 2007, s. 14, cit. $\checkmark$ pozn. 7.

22 Ibidem; LEWIS, Alan a CORNETTE, Anji. Contracting for Services. Proceedings of the Sounds Savings: Preserving Audio Collections Conference [online]. Austin: University of Texas School of Information, 2004. s. 93. [cit. 2020-08-25].

Dostupné z: http://www.arl. org/storage/documents/publications/sound-savings.pdf.

23 LEWIS a CORNETTE 2004,

s. 93, cit. v pozn. 22.

24 KLINGER 2007, s. 10, cit. $v$ pozn. 7. Srov. WILE 1995,

s. 165 , cit. $v$ pozn. 11 .

25 SHAMBARGER 1995,

s. $146-147$, cit. $v$ pozn. 6. 26 Celkové množství obalů neodpovídá počtu 1158 válečků z toho dưvodu, že dva nosiče ve sbírce ČMH jsou uloženy bez jakéhokoliv ochranného obalu.

27 Preservation SelfAssessment Program (PSAP) I Grooved Cylinder [online].

Preservation Self-Assessment Program (PSAP) [cit. 2020-

08-14]. Dostupné z: https:// psap.library.illinois.edul collection-id-guide/cylinder

28 Monroe 2008, s. 7, cit. $v$ pozn. 14. katalogové číslo atd.). V souvislosti se zaváděním odlévaných prefabrikátů byly fonografické válečky opatřeny těmito údaji pro snazší identifikaci na jednom ze svých okruží. U hnědých fonografických válečků, které na svém okruží z drtivé většiny nenesou žádné údaje, tento fakt výrazně ztěžuje určení nahrávky. ${ }^{20}$ Při správě a evidenci muzejních sbírek fonografických válečků i na základě zkušenosti sběratelů byl zaznamenán častý jev, kdy v průběhu času docházelo $\mathrm{k}$ záměně původní krabičky a příslušného nosiče, případně k sekundárnímu využívání prázdných ochranných obalů. Výrobci a distributoři se u originálních ochranných obalů snažili zajistit alespoň elementární ochranu nosičů, aby nedocházelo k jejich poškození. U hnědých válečků se v některý případech setkáváme s vnitřní výplní z buničité vaty, která byla vložena (či přímo napěchována) do dutého prostoru ve středu válečku uloženého v ochranném obalu. Její okraj byl přehnut přes okruží válečku tak, aby ochránil i záznamovou plochu nosiče. V dostupné literatuře je popsáno poškození, kdy kombinací uložení a nepříznivých klimatických podmínek docházelo $\mathrm{k}$ přilnutí bavlněných vláken $\mathrm{v}$ drážkách, čímž byla zvuková stopa na válečku poškozena. ${ }^{21}$

V období masové výroby prefabrikovaných fonografických válečků z černého vosku docházelo i k vylepšení jejich ochranných obalů. Krabičky byly opatřeny úzkou vrstvou kvalitní bavlněné výstelky, která těsně přiléhala $\mathrm{k}$ vnějšímu obvodu válečku a chránila ho před otřesy a mechanickým poškozením. U tohoto druhu krabiček již nemělo docházet v takové míře k ulpívání vláken v drážkách válečků. Kromě ulpívání vláken byla v literatuře buničitá vata spojována i s mikrobiologickým napadením, a to zejména kvůli své hygroskopicitě. ${ }^{22}$ Často se setkáváme s tvrzením, že i samotný charakter a použitý materiál ochranných obalů způsobuje zadržování vlhkosti a tím může opět docházet ke zvýšenému riziku mikrobiologického napadení uvnitř obalu. ${ }^{23}$ Současně je v literatuře popsáno poškození, které ani přes stejný vnější projev není znakem rozrůstajícího se mycelia, ale „výkvětem“ části užitého materiálu - matrice, př́ípadně kombinací obou jevů. ${ }^{24}$

Tradiční lignocelulózové ochranné tubusy mají jedinečnou schopnost vyrovnávat pomalu výkyvy teploty a relativní vlhkosti okolního vzduchu. Pro historické uložení, kdy nebylo možné zajistit prostředí s konstantní teplotou a vzdušnou vlhkostí, se tak pravděpodobně jednalo o nejlepší možnou volbu.

Ochranné obaly z lepenky nebyly jediným historickým zpưsobem uchovávání. Tehdejší posluchači fonografư a vlastníci sbírek fonografických válečků velmi často vyjímali nosiče z krabiček a umistovali je do specializovaných úložných prostorů. Za takové sloužily skříně s šuplíky, mobilní kufř́iky s přihrádkami či tzv. kabinety, které byly velmi často součástí konstrukce samotných fonografů. Ty mnohdy obsahovaly různé zásuvky a poličky s dřevěnými trny, na které byly válečky nasazeny v prevenci před pádem. ${ }^{25}$

Dalším důležitým faktorem, ovlivňujícím životnost válečků jsou podmínky jejich dlouhodobého uložení. Fyzický stav fonografických válečků je ohrožen především vnějšími činiteli, at’ už neodbornou manipulací, nárazem, znečištěním, nepatřičným umístěním, či nevhodnými klimatickými podmínkami během uchovávání. Doporučené hodnoty teploty a relativní vlhkosti vzduchu pro dlouhodobé uložení fonografických válečků se v dostupné literatuře neshodují na přesném rozmezí. Nicméně průnikem všech doporučujících návrhů jsou relativně nízké teploty $\left(8-12 \pm 1{ }^{\circ} \mathrm{C}\right)^{27}$, což odpovídá i praxi uchovávání jedné $\mathrm{z}$ největších světových sbírek fonografických válečků uložené v National Audiovisual Conservation Center v rámci Kongresové knihovny USA. ${ }^{28}$ Pro kratší dobu archivního uložení (cca do 10 let) připouští Association for Recorded Sound Collections (ARSC) teploty až do $20{ }^{\circ} \mathrm{C} .{ }^{29}$ Nízká teplota je doporučována zejména kvůli předcházení tvarovým deformacím. ${ }^{30}$

Z hlediska relativní vlhkosti vzduchu je pro krátkodobou archivaci (cca do 10 let) doporučováno rozmezí 30-50 \% RV. Pro 
dlouhodobé uložení (více než 10 let) je 25-35\% RV. ${ }^{31}$ Vlhkost bývá $\mathrm{v}$ prrípadě fonografických válečků zmiňována často v souvislosti s výskytem plísní. Klíčová je $\mathrm{v}$ tomto směru proto také cirkulace vzduchu v místech uložení. ${ }^{32}$

V optimálním př́padě by proto nosiče měly být vyjmuty $\mathrm{z}$ původních obalů a uloženy odděleně. $\mathrm{V}$ praxi se rovněž využívá přemístění a uchovávání v nových specializovaných archivních obalech. Kongresová knihovna ve spolupráci s experty ze sdružení ARSC vyvinula po mnoha letech výzkumu $\mathrm{v}$ tomto odvětví doposud pravděpodobně nejmodernější a nejvhodnější ochranné archivní obaly. ${ }^{33}$ Stejně jako $u$ většiny jiných archiválií je i u fonografických válečků doporučováno vyvarovat se větším teplotním i vlhkostním výkyvům. Tyto mohou kromě jiného způsobit vnitřní pnutí a následné praskliny ve hmotě válečku. Tento problém je spojen zejména s některými sériemi křehkých válečků z černého vosku (např. Edison Amberol). ${ }^{34}$

\section{Identifikace materiálů ochranných obalů, hnědých a černých fono- grafických válečků a degradačních produktů}

$\mathrm{Na}$ základě archivního průzkumu (tab. 2) bylo k bližší charakterizaci vybráno pět druhů nejčastěji se vyskytujících tato hodnota navrhována ještě nižší, a to
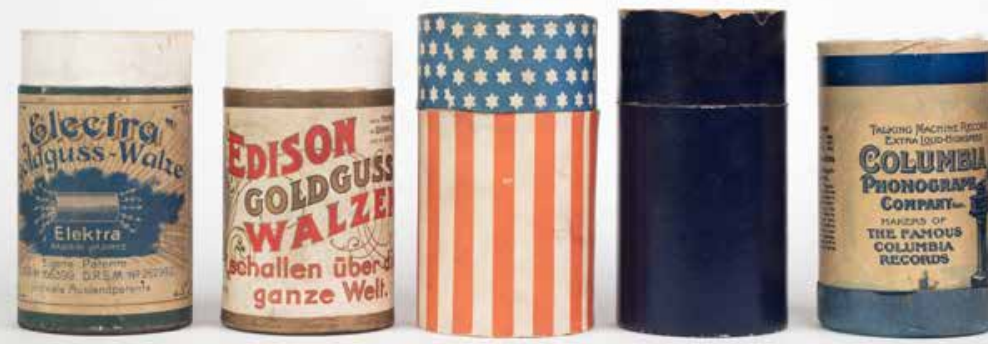

ochranných obalů s rozdílnými etiketami (obr. 2):

Ochranné obaly s etiketou / obchodní značkou:

- Edison Goldguss Walze (1902-12) celkový počet 508

- Columbia Cotton-Lined Box (19031909) $)^{35}$ - celkový počet 255

- Electra (Elektra) - celkový počet 26

Ochranné obaly bez etikety / obchodní značky

- Světle modrý Euro Box (zaveden roku 1898) ${ }^{36}$ - celkový počet 46

- Ochranný obal s designem americké vlajky - celkový počet 14

Hnědé a černé válečky

Materiálové složení hnědých a černých válečků je sice patentově a v odborné literatuře dobře podchyceno, přesto byla provedena široká instrumentální analýza jak samotné hmoty válečků, tak degradačních produktů na reprezentativním

Tab. 2. Hlavní etikety na ochranných obalech fonografických válečků ve sbírce.

\begin{tabular}{|l|l|}
\hline Etikety na ochranných obalech & Počet [ks] \\
\hline Edison & 626 \\
\hline Columbia & 265 \\
\hline Electra (Elektra) & 26 \\
\hline Ochranný obal s francouzským nápisem Ne Sont ni repris ni échangés & 21 \\
\hline Gloria Goldguss-Walze & 9 \\
\hline Čechie & 6 \\
\hline Pathé & 4 \\
\hline Apollo Record & 3 \\
\hline Bettini & 2 \\
\hline Ochranné obaly bez označené etikety & $194^{26}$ \\
\hline
\end{tabular}

Obr. 2. Nejvíce zastoupené druhy původních ochranných obalů na fonografické válečky ve sbírce fonotéky ČMH.

29 BRYLAWSKI, Samuel, et al. ARSC guide to audio preservation. Washington, DC: National Recording Preservation Board of the Library of Congress. 2015, s. 69. Dostupné na: https://clir. wordpress.clir.org/wp-content/ uploads/sites/6/2015/05/ARSCw-cover.pdf.

30 SHAMBARGER 1995, s. 146 , cit. $v$ pozn. 6.

31 BRYLAWSKI 2015, s. 69, cit. $\checkmark$ pozn. 29.

32 SHAMBARGER 1995, s. 146, cit. $v$ pozn. 6.

$33 \mathrm{~K}$ problematice uchovávání fonografických válečků a zvukových nosičù obecně viz BRYLAWSKI 2015, s. 69, cit. $\checkmark$ pozn. 29. $V$ českém prostředí viz NOVOTNÁ, Helena. Návrh modelového řešení pro dlouhodobé uchovávání vybraných typů zvukových dokumentů v pamětových institucích České republiky. Diplomová práce. Brno: Filozofická fakulta, Masarykova univerzita, 2018. 34 SHAMBARGER 1995, s. 146, cit. $v$ pozn. 6.

$35 \mathrm{~K}$ dataci jednotlivých druhů ochranných obalů viz KLINGER Bill. Archival Cylinder Box: An ARSC Design and Engineering Project [online]. 41st Annual ARSC Conference, 2007 May 3-5, Milwaukee, Wisconsin, USA [cit. 202008-03]. Dostupné z: http:// www.thejts.org/wp-content/ uploads/2008/03/Klinger.pdf. $36 \mathrm{Ibidem}$. 
Tab. 3. Analyzované hnědé a černé voskové fonografické válečky.

\begin{tabular}{|c|c|c|c|c|}
\hline Titul, etiketa obalu & Inv. .̌. & Datace nahrávky & Barva & Číslo vzorku \\
\hline $\begin{array}{l}\text { Árie z Rusalky, zpěv Bohumil Pták; obal bez } \\
\text { etikety (mimo typologii) }\end{array}$ & MH 988 & $1902-05$ & světle hnědá & $20-113-1$ \\
\hline $\begin{array}{l}\text { Sousedská, Kapela p. pl. č. } 102 \text { (Columbia 45080); } \\
\text { obal Columbia }\end{array}$ & MH 1156 & 1905 & černá & $20-113-3$ \\
\hline $\begin{array}{l}\text { Carmen (Columbia Walzen); obal bez etikety } \\
\text { (design americké vlajky) }\end{array}$ & MH 1103 & nedatováno & světle hnědá & $20-113-4$ \\
\hline $\begin{array}{l}\text { Z prostonárodní písně, Růžena Lžičková; obal } \\
\text { Edison Gold Guss Walze }\end{array}$ & MH 1157 & $\begin{array}{l}\text { 14. 11. } 1934 \\
\text { (přípisek na víčku) }\end{array}$ & světle hnědá & $20-113-5$ \\
\hline Bez označení, obal bez etikety (tzv. Euro Box) & MH 1158 & nedatováno & $\begin{array}{l}\text { tmavě } \\
\text { hnědá }\end{array}$ & $20-113-6$ \\
\hline $\begin{array}{l}\text { Die Post im Walde (Columbia 57109); obal } \\
\text { Columbia }\end{array}$ & MH 194 & nedatováno & černá & $20-113-7$ \\
\hline $\begin{array}{l}\text { Chodíval k nám. Kamaráde nepíj. Zpěv } \\
\text { Krampera; obal bez etikety (design americké } \\
\text { vlajky), výplň z buničité vaty }\end{array}$ & MH 54 & 1902-1905 & světle hnědá & $20-113-8$ \\
\hline
\end{tabular}

výběru vzorků fonografických válečků (tab. 3). Drobné rozdíly ve výsledcích analýz tak mohou být dobrým korektivem při časovém vročení, při popisu technologických odlišností výroby či vlivu prostředí při jejich uložení (zejména $\mathrm{v}$ souvislosti s umístěním nosičů v původních obalech). Reprezentativní vzorky pro analýzu byly vybrány právě s tímto ohledem, tak aby válečky vykazovaly degradační poškození vizuálně podobné mikrobiologickému napadení. Převládají zde válečky z hnědého vosku, u nichž byly viditelné stopy degradace (v kombinaci s obaly s různou etiketou) zaznamenány častěji než u válečků z černého vosku. Zahrnuty byly i dva vzorky černých voskových válečků značky Columbia odlišných číselných sérií, které jsou umístěny v obalech s etiketou stejné firmy (obal Columbia Cotton-Lined Box, viz přehled výše). Tato kombinace (černý voskový váleček Columbia/obal Columbia) se jeví jako problémová - degradace u ní byla zaznamenána v 81 př́ipadech.

\section{Metody průzkumu}

\section{Ochranné obaly}

Průzkum vrstvené struktury ochranných obalů fonografických válečků probíhal pomocí USB mikroskopu AM4113T-FV2W
Dino-Lite ve viditelném světle (VIS). Identifikace morfologických znaků tkané výstelky tubusů byl proveden pomocí optického mikroskopu Olympus BX 60 v procházejícím viditelném světle.

\section{Fonografické válečky}

$\mathrm{V}$ rámci materiálového průzkumu fonografických válečků byla realizována makroskopická dokumentace povrchu válečků a vzorků USB mikroskopem AM4113ZTFV2W Dino-Lite Premier při zvětšení 50×, $200 \times$ v polarizovaném viditelném světle (VIS) a v ultrafialovém světle $(\lambda=375 \mathrm{~nm})$. Na válečcích byla provedena prvková identifikace metodou rentgenové fluorescenční analýzy přenosným př́strojem NITON XL3t GOLDD+. Zdrojem záření byla minirentgenka s Ag anodou o maximálním napětí $50 \mathrm{kV}$ a velkoplošným SDD+ detektorem. Měření byla provedena bezkontaktně ze vzdálenosti do cca $0,5 \mathrm{~cm}$, měřená plocha byla cca o průměru $0,3-0,5 \mathrm{~cm}$. Doba jednoho měření byla cca $120 \mathrm{~s}$.

$Z$ válečků byly následně odebrány mikrovzorky, které byly umístěny na uhlíkovou pásku na hliníkovém nosiči. Vzorky byly dokumentovány na elektronovém mikroskopu JEOL JSM 6460 v režimu zpětně odražených elektronů (BSE), 
ve vysokém vakuu, při urychlovacím napětí $15 \mathrm{keV}$. Prvkové složení vzorků bylo určeno na skenovacím elektronovém mikroskopu JEOL JSM-6460 LA s energiově-disperzním detektorem (SEM-EDS). Zdrojem elektronů bylo wolframové vlákno. Snímání se provádělo v režimu zpětně odražených elektronů (BSE). Měření probíhala ve vysokém vakuu při urychlovacím napětí $20 \mathrm{keV}$.

Další kvalitativní analýza byla realizována metodou infračervená spektroskopie na spektrometru ALPHA (Bruker) ATR technikou s jednoodrazovým diamantovým krystalem. Měření probíhalo v rozsahu $375-4000 \mathrm{~cm}^{-1} \mathrm{~s}$ rozlišením $2 \mathrm{~cm}^{-1}$, při počtu 128 skenů. Komplementárně byla provedena analýza metodou Ramanovy

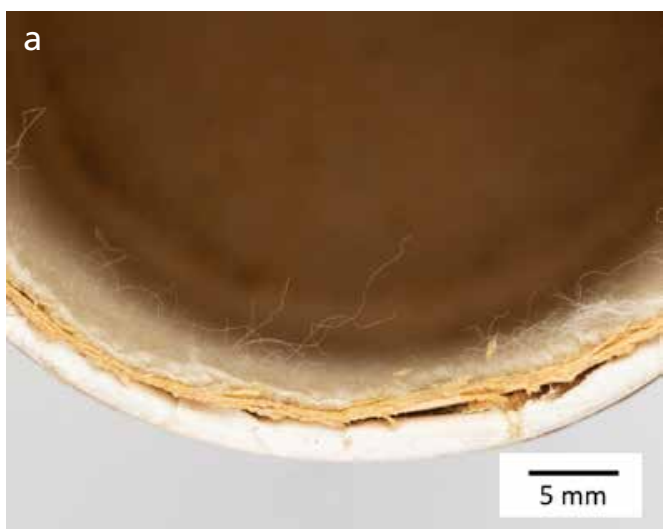

spektroskopie na spektrometru DXR Raman Microscope od firmy Thermo Scientific ve spojení s konfokálním mikroskopem Olympus. Měření probíhalo $v$ rozsahu $50-3300 \mathrm{~cm}^{-1} \mathrm{~s}$ rozlišením $4 \mathrm{~cm}^{-1}$, při použití NIR laseru $780 \mathrm{~nm}$ (diodový laser) a zeleného laseru $532 \mathrm{~nm}$ (diodový laser). Doba měření byla 180 s, při výkonu laserů od 1 do $24 \mathrm{~mW}$, resp. 1-10 mW.

\section{Výsledky a diskuse}

\section{Ochranné obaly}

Vybrané druhy ochranných obalů vykazovaly během průzkumu velké množství společných rysů. Tělo tubusu je tvořeno vícevrstvým materiálem lignocelulózového charakteru. Jedná se o jednu až dvě

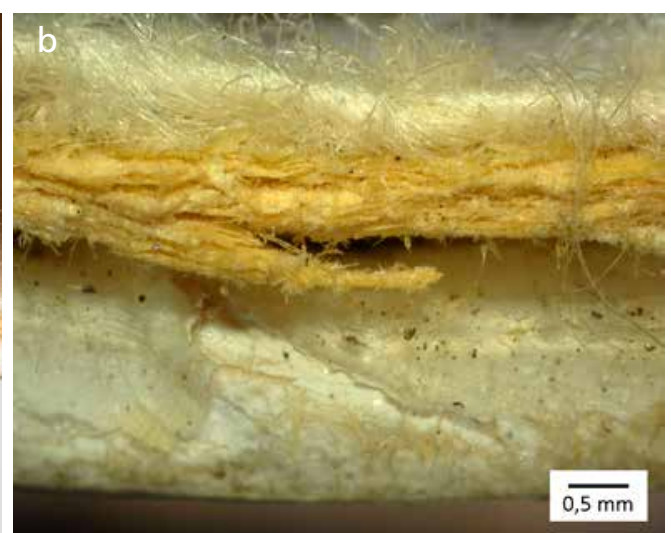

Obr. 3. Ochranný tubus série Edison Goldguss Walze (1902-12) se dvěma vrstvami lepenky a navazující bavlněnou výstelkou. Makroskopická fotografie (a) a mikroskopický snímek (b), obojí foceno $v$ kolmém pohledu a dopadajícím bílém světle.
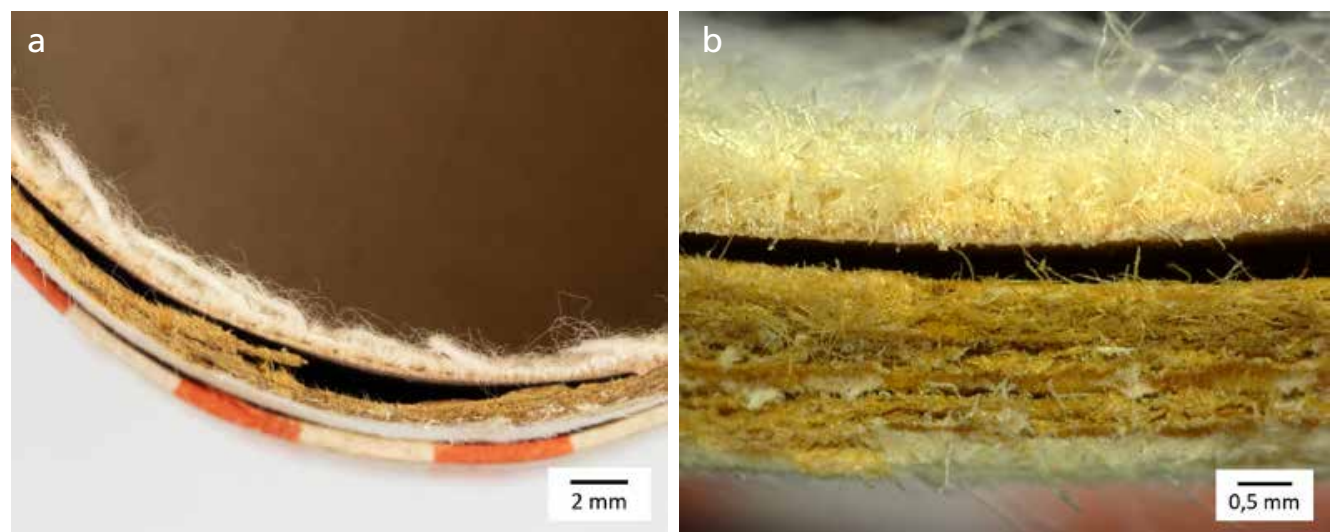

Obr. 4. Ochranný tubus bez etikety s designem americké vlajky s jednou vrstvou lepenky a navazující vrstvou bavlněné výstelky, podlepené tenkým lignocelulózovým materiálem. Makroskopická fotografie (a) a mikroskopický snímek (b), obojí foceno v kolmém pohledu a dopadajícím bilém světle. 
Obr. 5. Mikroskopické snímky vláken odebraných z tkané výstelky. Snímky byly pořízeny v procházejícím světle s paralelními (a) a zkříženými (b) nikoly. Na obrázcích je zjevný tvar stočené stuhy, charakteristický pro bavlnu.

37 Potvrzeno fluoroglucinolovým testem (Wiesnerova reakce) na prítomnost drevoviny, viz SOUKUP, Aleš. Selected Simple Methods of Plant

Cell Wall Histochemistry and Staining for Light Microscopy. Methods in molecular biology, 2014 , vol. 1080 , s. 25-40.

38 Bavlněné vlákno vykazuje charakter stužkovitého útvaru se zřetelnými zákruty viz KUDLÁČEK, Ladislav, a RU゚ŽIČKA, Jaroslav. Struktura a vlastnosti textilních vláken; Pardubice: VŠCHT Pardubice, 1988 , s. 55. 39 KLINGER 2007, cit. $v$ pozn. 35.

40 Hlavními surovinami byly minerální vosk (ceresin), kyselina stearová, stearát sodný

a hlinitý. Dále byl používán i hydroxid sodný, uhličitan sodný, hliník či měděný prášek.

Do černých válečků se rovněž přidával karnaubský vosk

a lampová čerň (saze), viz WILE

1995, s. 165, cit. v pozn. 11.

41 WILE 1995, s. 166-168,

cit. v pozn. 11.; AYLSWORTH, Jonas W. Composition for Making Duplicate PhonographRecords. U.S. Patent, 782,375 1914-02-14; AYLSWORTH, Jonas W. Composition for Making Duplicate PhonographRecords. U.S. Patent, 880,707. 1908-03-03.

42 WILE 1995, s.168, cit. v pozn. 11., MONROE 2008, cit. $\checkmark$ pozn. 14.
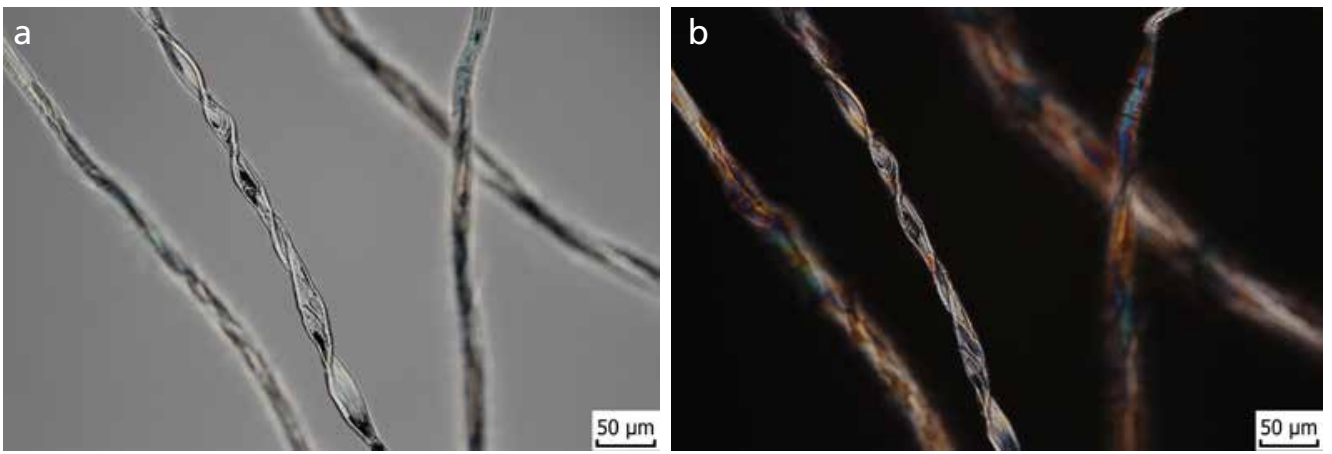

vrstvy lepenky různé tlouštky a povrchové úpravy s vysokým obsahem dřevoviny. ${ }^{37}$ Vnitřní vrstva tubusu je opatřena tkanou výstelkou (obr. 3, 4). Mikroskopická identifikace vláken tkané výstelky potvrdila jejich předpokládaný bavlněný charakter (obr. 5). ${ }^{38}$ Kromě bavlněné výstelky byla jako problematická označena v literatuře také vnitřní výplň z buničité vaty, a to kvůli vláknitým reziduím na povrchu válečků. ${ }^{39}$ Po prohlídce povrchu válečků z fonotéky ČMH uchovávaných s výplní z buničité vaty (s celkovým počtem $23 \mathrm{v}$ celé sbírce) se nepodařilo tento jev potvrdit.

\section{Fonografické válečky}

Makro fotodokumentace hnědých válečků ukázala variabilitu zabarvení použité hmoty od světle okrové po tmavě hnědou (obr. 6). Černý váleček má šedočerné až hnědočerné zabarvení vykazující mírně lesklý povrch s pravidelným rýhováním. Některé vzorky válečků jak hnědých, tak černých vykazují degradační poškození v podobě lokalizovaných bělavých struktur na povrchu (obr. 7). Tento bělavý povlak má bud' charakter vláken s drobnými vlásečnicemi (obr. 7b), nebo jsou viditelné krystalické struktury procházející pod povrchem voskového válečku (obr. 7a). Dále lze pozorovat kombinaci výkvětů vláknitého charakteru a drobných oblých útvarů (obr. 7c), a $\mathrm{v}$ některých případech dochází i $\mathrm{k}$ výskytu souvislé bělavé vrstvy na povrchu válečků (obr. 7d). Rozdílná struktura byla dokumentována i v elektronovém mikroskopu, kde jsou rozpoznatelné druhově rozmanité morfologické struktury výkvětů (obr. 8).

Z dokumentace struktury a absence fluorescence výkvětů pod ultrafialovým světlem (obr. 9) lze usuzovat, že nejde o mikrobiologické napadení, ale že strukturu tvoří degradační minerální produkty z vlastní voskové hmoty válečků. Prvková analýza na elektronovém mikroskopu s energiově disperzním detektorem potvrdila prvkové složení (tab. 4), které odpovídá materiálům specifikovaným v odborné literatuře a používaným při výrobě. ${ }^{40}$

Dominantní je jednoznačně přítomnost uhlíku, který odpovídá základním složkám válečků. V prvkovém složení byl identifikován rovněž sodík a hliník, které mohly být použity ve formě soli kyseliny
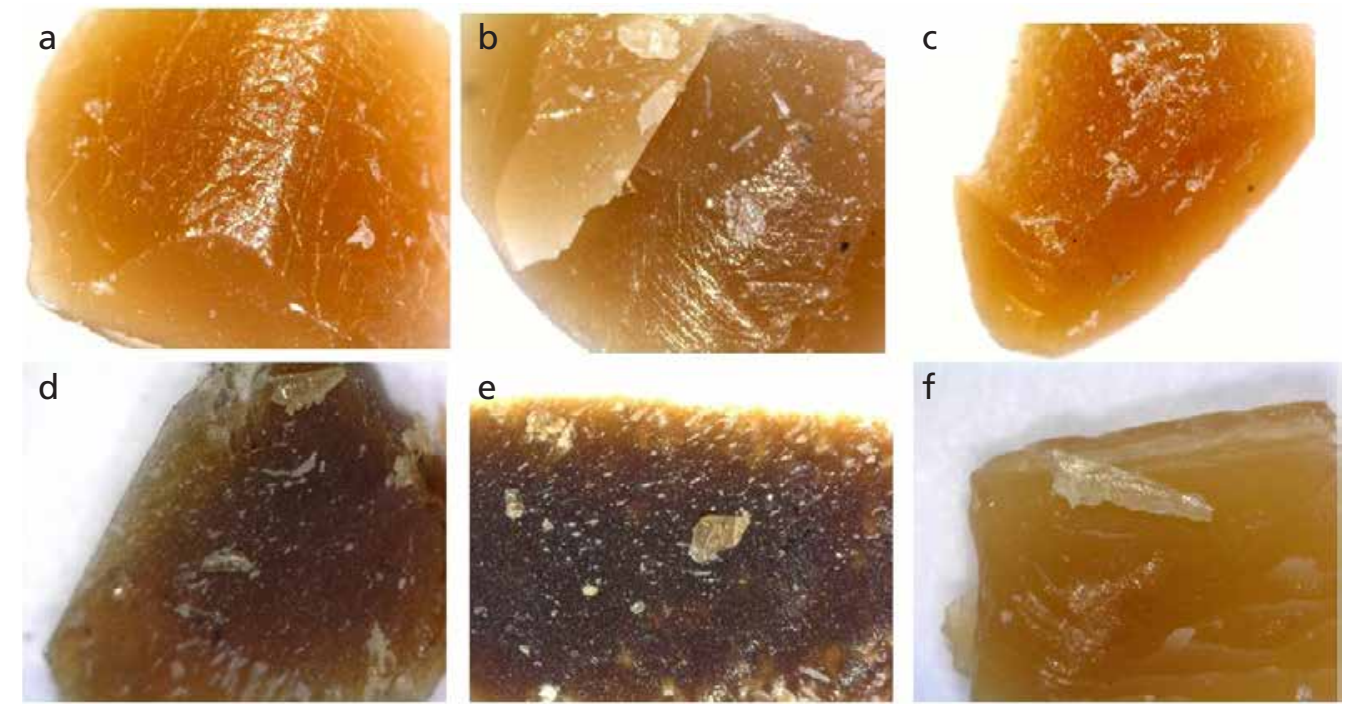

Obr. 6. Makrofotografie vzorků hmot z hnědých (a-d, f) a černého válečku (e). 
stearové, či v př́ípadě hliníku jako součást receptury. ${ }^{41}$ Ve světle hnědém válečku s výkvětem (MH54, vzorek 20-113-8) byla potvrzena ve hmotě př́tomnost baria. Jeho zdrojem může být eventuálně použité plnivo. Př́tomná měd' ve hmotě jednoho ze světle hnědých válečků (MH988, vzorek 20-113-1) může souviset se vstupními surovinami v používané receptuře. Ojediněle byl identifikován draslík a chlor, který má na černém válečku větší zastoupení právě ve vzniklém druhotném výkvětu na povrchu. Původem prrítomnosti těchto prvků může být předchozí neodborná manipulace. Patrný je semikvantitativní rozdíl $\mathrm{v}$ zastoupení jednotlivých prvků zejména sodíku a hliníku ve hmotě a ve výkvětech (tab. 4 a 5). Pod $0,5 \mathrm{hm} \%$ bylo na tmavě hnědých válečcích identifikováno i železo, které lze spojovat bud's použitím pigmentu (plnivo) pro ovlivnění barevné tonality hmoty, nebo se jedná o rezidua z výroby, kdy byla směs připravována $\mathrm{v}$ železných nádobách. ${ }^{42}$

Analýzou infračervenou spektroskopií byl vosk potvrzen jako základní složka hmot jak hnědých, tak černých válečků. Zatímco $\mathrm{v}$ hnědých je užit zřejmě pouze minerální vosk, tak $\mathrm{v}$ černých je pravděpodobně kombinace několika druhů.. ${ }^{43}$ Dále byly
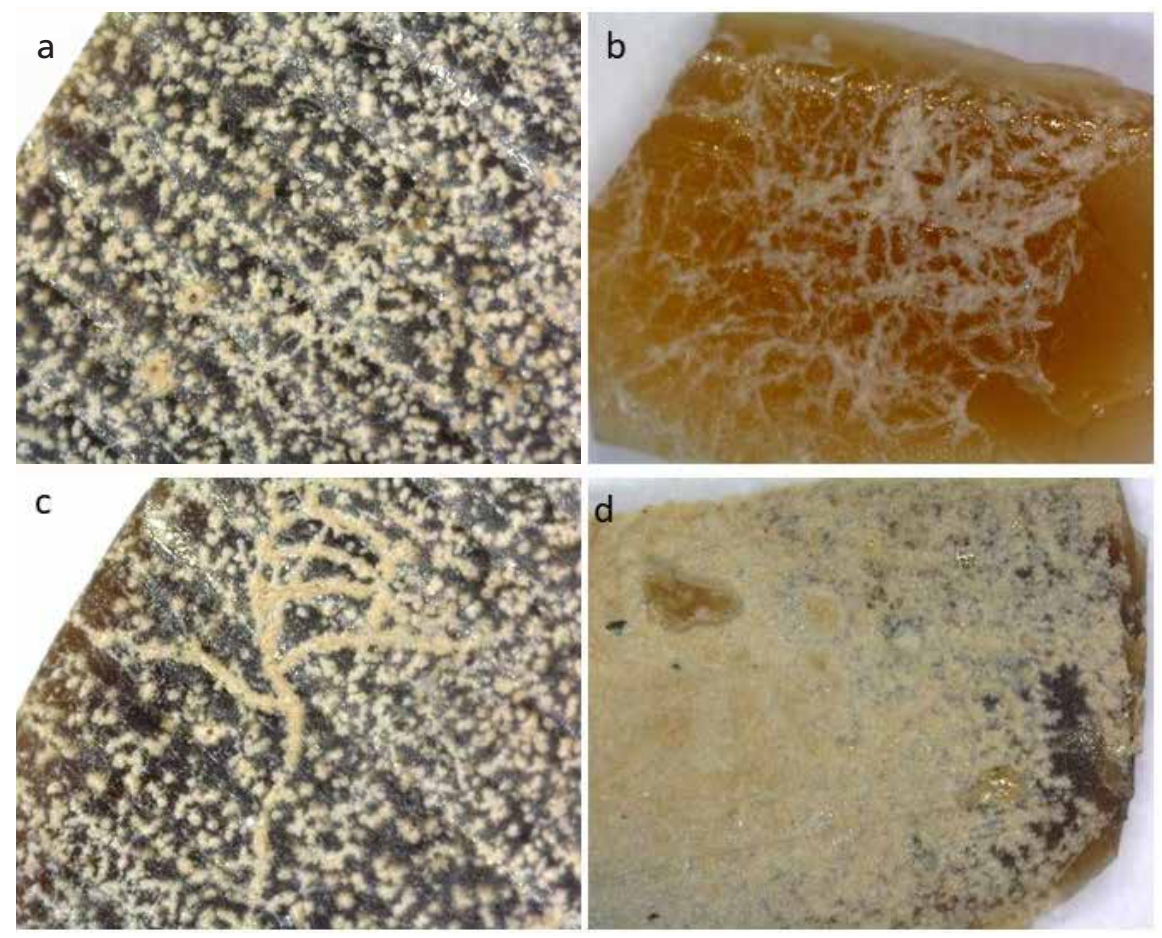

identifikovány soli kyseliny stearové, můžeme předpokládat použití stearátu sodného ev. hlinitého. Na některých vzorcích z bělavých výkvětů na povrchu byla potvrzena př́tomnost octanu sodného. Vznik octanu sodného na povrchu může souviset s nevhodným uložením fonografických válečků $\mathrm{v}$ ochranných tubusech $\mathrm{z}$ lepenky obsahující dřevovinu. $\mathrm{Z}$ tohoto materiálu se $\mathrm{v}$ průběhu přirozeného stárnutí uvolňuje kyselina octová (ve směsi s dalšími látkami) ${ }^{44}$, která následně reaguje $\mathrm{s}$ hmotou válečku. Na povrchu válečku tak může
Obr. 7. Makrofotografie výkvětů (degradačnich produktů): a) drobné útvary, kopírující směr drážek válečkư; b) vláknitý charakter; c) kombinace výkvětů; d) výkvět - kompaktní bělavý povlak na povrchu.

43 Kombinace minerálních a prírodních voskù viz WILE 1995, s. 164-6, cit. v pozn. 11.

Tab. 4. Výsledky prvkové analýzy EDS složení hmot voskových fonografických válečků v hm \% $(>0,5)$.

\begin{tabular}{|l|l|l|l|l|l|l|l|l|l|}
\hline Barva válečku & Číslo vzorku & $\mathbf{C}$ & $\mathbf{O}$ & $\mathbf{N a}$ & $\mathbf{A l}$ & $\mathbf{C l}$ & $\mathbf{K}$ & $\mathbf{C u}$ & $\mathbf{B a}$ \\
\hline světle hnědá & $20-113-1$ & 65,03 & 8,39 & 6,54 & 6,84 & & & 13,20 & \\
\hline černá & $20-113-3$ & 82,29 & 9,96 & 5,48 & 1,43 & 0,84 & & & \\
\hline světle hnědá & $20-113-4$ & 77,82 & 12,46 & 7,74 & 1,99 & & & & \\
\hline světle hnědá & $20-113-5$ & 78,99 & 13,70 & 6,49 & 0,82 & & & & \\
\hline tmavě hnědá & $20-113-6$ & 78,69 & 13,52 & 7,17 & 0,62 & & & & \\
\hline černá & $20-113-7$ & 65,80 & 21,01 & 9,81 & 2,60 & & 0,78 & & \\
\hline světle hnědá & $20-113-8$ & 75,46 & 10,49 & 7,10 & 0,73 & & & & 6,21 \\
\hline
\end{tabular}

Tab. 5. Výsledky prvkové analýzy EDS složení výkvětů na hmotách voskových fonografických válečků v hm \% (>0,5).

\begin{tabular}{|l|l|l|l|l|l|l|l|l|}
\hline Barva válečku & Č́slo vzorku & $\mathbf{C}$ & $\mathbf{O}$ & $\mathbf{N a}$ & $\mathbf{A l}$ & $\mathbf{C l}$ & $\mathbf{K}$ & $\mathbf{B a}$ \\
\hline černá & $20-113-3$ & 54,94 & 3,26 & 17,39 & 1,37 & 23,03 & & \\
\hline černá & $20-113-7$ & 70,68 & 18,56 & 8,45 & 2,31 & & & \\
\hline světle hnědá & $20-113-8$ & 69,77 & 12,70 & 7,72 & & & 0,59 & 9,22 \\
\hline
\end{tabular}


Obr. 8. Snímky výkvětů z elektronového mikroskopu $v$ režimu zpětně odražených elektronů (BSE): a) vláknitý charakter; b) kombinace výkvětů $v$ podobě drobných útvarů a vláknitého charakteru; c) výkvět - kompaktní bělavý povlak na povrchu.
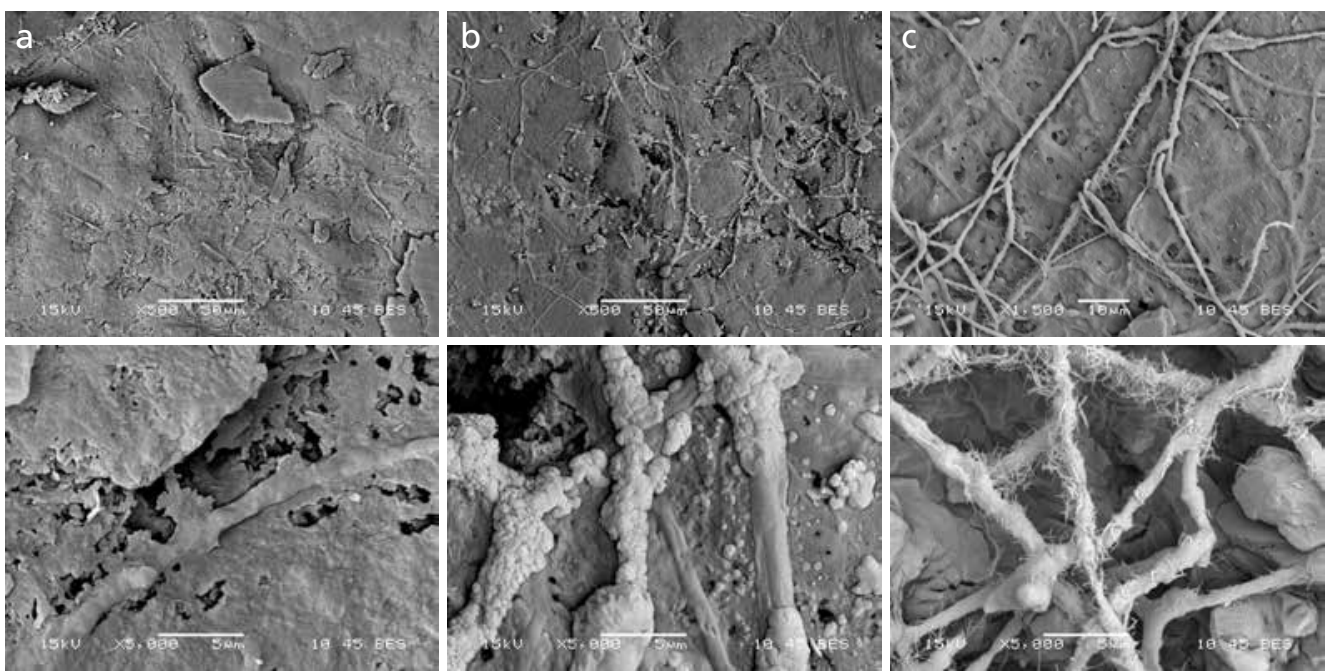

docházet k substituci a vzniku octanu sodného ze stearátu sodného použitého při výrobě. Analogicky je možné předpokládat i reakci sloučenin hliníku. Z rozdílných morfologických znaků struktur na jednotlivých válečcích můžeme usuzovat, že mechanismus vzniku výkvětů probíhal více než jedním způsobem. S podobným jevem je možné se setkat u voskových objektů (např. pečetí), kde bělavé výkvěty způsobují zejména lineární nenasycené alkeny s 31 a 33 uhlíky v řetězci. ${ }^{45}$ Pro bližší charakterizaci jak výkvětů, tak přítomných vosků bude $\mathrm{v}$ budoucnu průzkum

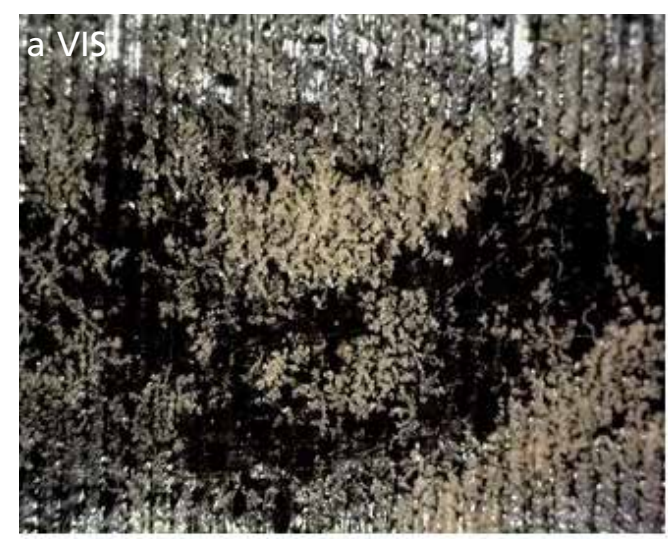

rozšířen o další specializované instrumentální analýzy, při kterých by bylo možné jednotlivé složky oddělit a charakterizovat je samostatně.

\section{Závěr}

Na základě provedeného průzkumu byl zpracován statistický přehled charakteristik fonografických válečků a jejich ochranných obalů ve sbírce fonotéky ČMH. V současnosti se ve sbírce nachází 1158 evidovaných fonografických válečků, z toho je 224 hnědých a 932 černých. Ochranné obaly jsou zastoupeny převahou
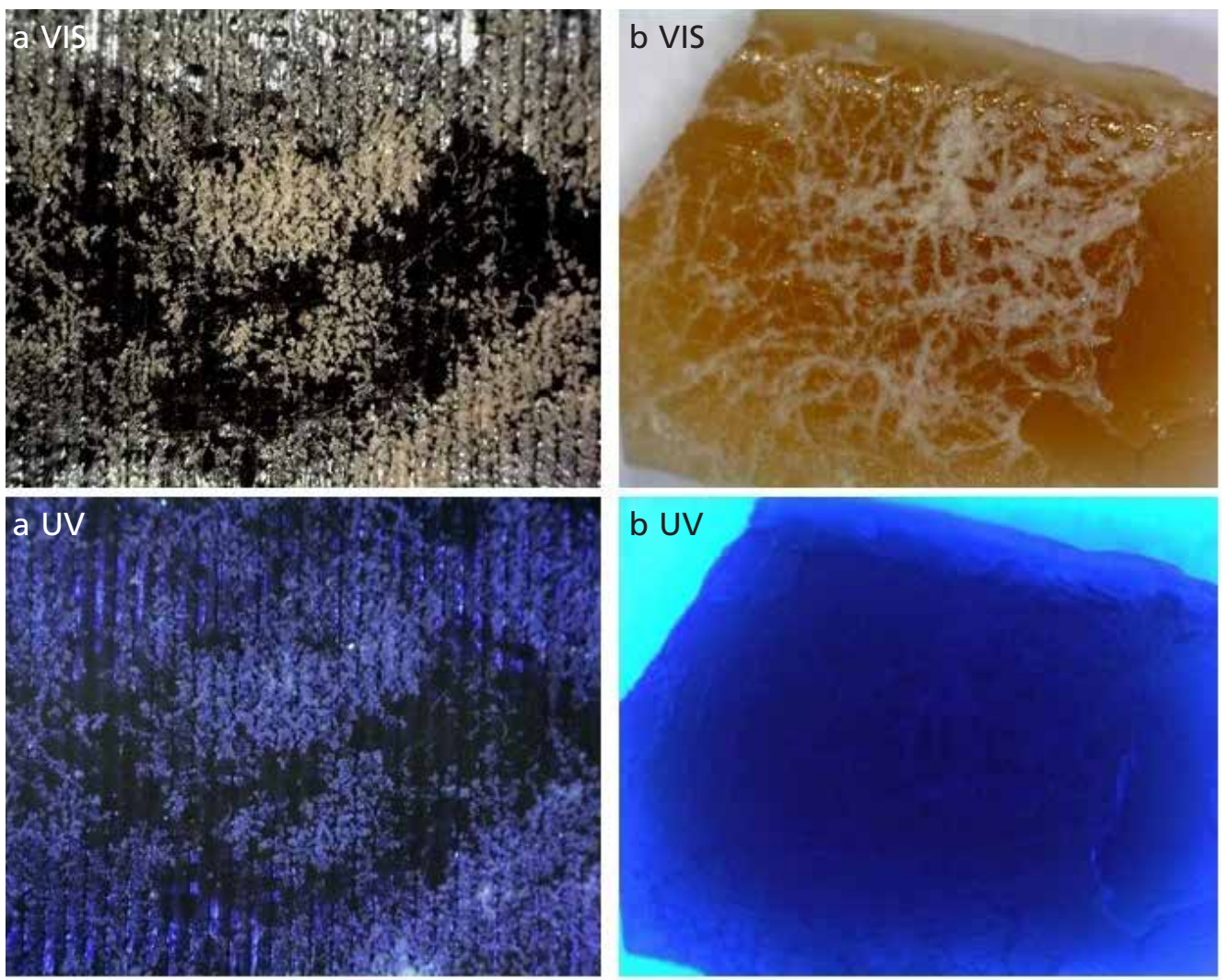

Obr. 9. Výkvěty na povrchu ve viditelném a ultrafialovém světle. 
etiket firem Edison (626) a Columbia (265), s velkým poměrem evropských/ lokálních variant (např. německá etiketa Edison Goldguss čítá celkem 508 obalů). I přes historicky hodnotný soubor fonografických válečků z hnědého vosku jsou tak ve sbírce obsaženy převážně komerční masově produkované válečky z černého vosku pocházející z rozmezí let 1902-1912. Velké množství nosičů vykazuje v různé míre degradační poškození ve formě bělavého povrchu. Přestože byl tento degradační „výkvět" původně považován za produkt mikrobiologického napadení, způsobený nevhodným uložením v původních ochranných obalech, prvotní analýzy naznačují, že by se mohlo spíše jednat o „výkvět,“" vzniklý vlivem degradačních procesů $\mathrm{v}$ samotné hmotě válečků. Na části vzorků byl prokázán ve výkvětu octan sodný, jehož vznik souvisí pravděpodobně s nevhodným uložením fonografických válečků. Analýza matrice válečků se v základních bodech shoduje $\mathrm{s}$ údaji $\mathrm{v}$ dostupné literatuře. Bližší charakterizace matrice, výkvětů a procesů jejich vzniku jsou předmětem dalších specializovaných analýz. Získané poznatky mohou být základním korektivem při optimalizaci postupů preventivní konzervace a ochrany fonografických válečků.

Ideální podmínky uložení jsou v dostupných zdrojích většinou uvedeny univerzálně pro zvukové nosiče bez určení konkrétních hodnot pro jejich jednotlivé typy (fonografické válečky, gramofonové desky atd.). V budoucnu by bylo vhodné tato obecná doporučení ověrit a př́ípadně lépe vymezit a specifikovat ideální podmínky pro druhově variabilní materiály zvukových nosičů - fonografických válečků (v našem př́ípadě různé druhy vosku, celuloid atd.).

\section{Literatura}

AYLSWORTH, Jonas W. Composition for Making Duplicate PhonographRecords. U.S. Patent, 880,707. 1908-03-03. AYLSWORTH, Jonas W. Composition for Making Duplicate PhonographRecords. U.S. Patent, 782,375 1914-02-14.
BARTL, Benjamin, et al. Analysis of efflorescence on surface of beeswax seals. Journal of Cultural Heritage, 2012, vol. 13, s. 275-284.

BARTL, Benjamin, et.al. 'Wax bloom' on beeswax cultural heritage objects: Exploring the causes of the phenomenon. Magn. Reson. Chem. 2015, vol. 53, s. 509-513.

BOSTON, George, et al. Handling and storage of audio and video carriers: IASATC 05 [online]. London: International Association of Sound and Audiovisual Archives, 2014. [cit. 2020-08-14]. Dostupné na: https://www.iasa-web. org/handling-storage-tc05

BRYLAWSKI, Samuel, et al. ARSC guide to audio preservation [online]. Washington, DC: National Recording Preservation Board of the Library of Congress, 2015. [cit. 2020-07-28]. Dostupné z: https://clir. wordpress.clir.org/wp-content/uploads/ sites/6/2015/05/ARSC-w-cover.pdf

Ceresin wax [online]. CAMEO Materials Database [cit. 2020-11-18]. Dostupné z: http://cameo.mfa.org/wiki/Ceresin_wax. GELATT, Roland. The Fabulous Phonograph. Philadelphia and New York: J.B. Lippincott Company, 1954.

GÖSSEL, Gabriel. Fonogram 1: Praktický průvodce historii záznamu zvuku. Praha: Radioservis, 2001.

GÖSSEL, Gabriel a ŠÍR, Filip. Recorded Sound in the Czech Lands 1900-1946. Brno: Moravská zemská knihovna, 2016.

HOSŤÁK, Jan. Katalog fonografư ve sbírkách NTM. Praha: NTM, 2018.

KLINGER Bill. Archival Cylinder Box: An ARSC Design and Engineering Project [online]. 41st Annual ARSC Conference, 2007 May 3-5, Milwaukee, Wisconsin, USA [cit. 2020-08-03]. Dostupné z: http://www.thejts.org/wp-content/ uploads/2008/03/Klinger.pdf.

KLINGER, Bill. Cylinder Records: Significance, Production, and Survival [online]. Library of Congress, 2007. [cit. 2020-07-08]. Dostupné z: https://www. loc.gov/static/programs/national-recording-preservation-board/documents/ klinger.pdf. 
KUBIČKA, Roman a ZELINGER, Jiří, Výkladový slovník malírství, grafiky a restaurátorství. Praha: Grada Publishing, 2004, s. 319-320.

KUDLÁČEK, Ladislav a RŮŽIČKA, Jaroslav. Struktura a vlastnosti textilních vláken. Pardubice: VŠCHT Pardubice, 1988.

LEWIS, Alan a CORNETTE, Anji. Contracting for Services. Proceedings of the Sounds Savings: Preserving Audio Collections Conference [online]. Austin: University of Texas School of Information, 2004, s. 91-106. [cit. 202008-25]. Dostupné z: https://www.arl. org/wp-content/uploads/2004/12/sound-savings.pdf.

MESZNER, Jindřich. Přehled zoukového průmyslu: studijní materiály. Strojopis, 1984.

MLEZIVA, Josef. Polymery - výroba, struktura, vlastnosti a použití. Praha: Sobotáles, 1993, s. 340-342.

MONROE, Eric B. Uncovering the nature of damage to early wax cylinder audio recordings during storage [online]. AES International Conference on Audio Archiving, Preservation and Restoration, 2018 June 7-9, Culpeper, VA, USA [cit. 2020-07-02]. Dostupné z: https://www. aes.org/e-lib/browse.cfm?elib=19591

MORTON, David. Sound recording: the life story of a technology. Baltimore, Md.: Johns Hopkins University Press, 2006, s. 26-28.

NOVOTNÁ, Helena. Návrh modelového řešení pro dlouhodobé uchovávání vybraných typů zoukových dokumentů v pamětových institucích České republiky. Diplomová práce. Brno: Filozofická fakulta, Masarykova univerzita, 2018.

PEDERSOLI, José Luis Junior et al. NonDestructive Determination of Acetic Acid and Furfural in Books by SolidPhase Micro-extraction (SPME) and Gas Chromatography-Mass Spectrometry (GC/MS). Restaurator, 2011, vol. 32, s. 110-134

Preservation Self-Assessment Program (PSAP) I Grooved Cylinder [online]. Preservation Self-Assessment Program (PSAP) [cit. 2020-08-14]. Dostupné z: https://psap.library.illinois.edu/ collection-id-guide/cylinder.

PROKOPOVÁ, Irena. Makromolekulární chemie. 2nd ed. Vysoká škola chemicko-technologická v Praze, Praha 2007, s. 200.

SHAMBARGER, Peter. Cylinder Records: An Overview. ARSC Journal, 1995, vol. 26, no. 2, s. 133-161.

SOUKUP, Aleš. Selected Simple Methods of Plant Cell Wall Histochemistry and Staining for Light Microscopy, Methods in molecular biology, 2014, vol. 1080, s. $25-40$.

STERNE, Jonathan. The Audible Past: Cultural Origins of Sound Reproduction. Durham: Duke University Press, 2003.

TAUBE, Edward. Carnauba Wax: Product of a Brazilian Palm. Economic Botany, 1952, vol. 6, no. 4, s. 379-401.

TULLOCH, A. P. Beeswax-composition and analysis. Bee World, 1980, vol. 61, s. 47-62.

WILE, Raymond R. Cylinder Record Materials. ARSC Journal, 1995, vol. 26, no. 2 , s. $162-171$. 